\title{
Seroepidemiological and socioeconomic studies of genital chlamydial infection in Ethiopian
} women

\author{
M E Duncan, Y Jamil, G Tibaux, A Pelzer, L Mehari, S Darougar
}

\begin{abstract}
Objective-To measure the prevalence of chlamydial genital infection in Ethiopian women attending gynaecological, obstet-

ric and family planning clinics; to identify the epidemiological, social and economic factors affecting the prevalence of infection in a country where routine laboratory culture and serological tests for chlamydial species are unavailable; to determine the risk factors for genital chlamydial infection in those with serological evidence of other sexually transmitted diseases.
\end{abstract}

Subjects-1846 Ethiopian women, outpatient attenders at two teaching hospitals and a mother and child health centre in Addis Ababa, Ethiopia.

Setting-Gynaecological outpatient department, antenatal, postnatal and family planning clinics.

Methods-Sera were tested for typespecific anti-chlamydial antibodies using purified chlamydial antigens (C. trachomatis A-C (CTA-C), C. trachomatis D-K (CTD-K), Lymphogranuloma venereum (LGV1-3), and C. pneumoniae (CPn)), in a micro-immunofluorescence test. The genital chlamydia seropositivity was analysed against patient's age, clinic attended, ethnic group, religion, origin of residence, age at first marriage and first coitus, income, number of sexual partners, duration of sexual activity, marital status/profession, obstetric and contraceptive history, and seropositivity for other sexually transmitted diseases.

Results-Overall exposure to chlamydia species was found in $84 \%$, genital chlamydial infection in $62 \%$, and titres suggestive of recent or present genital infection in $42 \%$ of those studied. Genital chlamydial infection was highest (64\%) in family planning and lowest (54\%) in antenatal clinic attenders. Exposure to genital chlamydia species was influenced by ethnic group and religion. Those married and sexually active under 13 years of age had greater exposure (69\%) to genital chlamydial infection than those first sexually active aged over 18 (46\%). Prevalence of infection was highest in those with more than five sexual partners $(78 \%)$ and in bargirls $(84 \%)$. The lowest income groups had a higher prevalence $(65 \%)$ of genital chlamydial infection than the wealthiest (48\%).

Multivariate analysis showed the most important factors to be age at first coitus, religion, prostitution and present age of the woman in that order. Risk for genital chlamydial infection was increased in those with seropositivity for syphilis, gonorrhoea, HSV-2 but not $\mathrm{HBV}$ infection.

Conclusion/Application-Chlamydial genital infections are highly prevalent in both symptomatic and asymptomatic Ethiopian women. The high prevalence of infection reported reflects a complexity of socioeconomic factors: very early age at first marriage and first coitus, instability of first marriage, subsequent divorce and remarriage or drift into prostitution, all of which are influenced by ethnic group, religion and poverty-together with transmission from an infected group of prostitutes by promiscuous males to their wives, lack of diagnostic facilities and inadequate treatment of both symptomatic and asymptomatic men and women. The problem of chlamydial disease in Ethiopia needs to be addressed urgently in the context of control of STD.

\section{Introduction}

In industrialised countries chlamydial genital infections and their complications such as epididymitis, pelvic inflammatory disease (PID) and infertility are considered to be amongst the commonest causes of genital morbidity. ${ }^{14}$ Recent studies have shown that chlamydial genital infection and its complications are as common, if not more common in some countries of Africa as in industrialised countries. $^{5-13}$

In Ethiopia sexually transmitted disease and its complications are common ${ }^{14}{ }^{16}$ and its high prevalence is associated with early age at first marriage and first coitus and prostitution. ${ }^{1617}$ Reports of genital chlamydial infection in Ethiopia are scarce. In one seroepidemiological study it was shown that the prevalence of chlamydial genital infections in women and men attending an STD clinic was $45 \%$ and $32 \%$ respectively. ${ }^{6}$ As far as we are aware there is no detailed information available regarding the epidemiological and socioeconomic factors associated with transmission of this infection in Ethiopia or the rest of Africa

As part of a larger study into the aetiological factors associated with STD and cervical cancer we investigated the prevalence of $C$. trachomatis genital infection and associated epidemiological and socioeconomic factors in women attending obstetric and gynaecological clinics in Addis Ababa. 
Patients, Methods and Materials

One thousand eight hundred and forty six Ethiopian women were studied after giving their informed consent. No sampling design was used. The women were recruited into the study from the following clinics in Addis Ababa: 960 symptomatic first attenders at the gynaecological outpatient department (GOPD), 481, 306 and 99 asymptomatic women from routine family planning (FPC), antenatal (ANC) and postnatal clinics (PNC) respectively. Permission to carry out this study, exporting patient data and clinical samples for analysis was obtained from the Ethiopian Ministry of Health.

Epidemiological and socioeconomic data for each patient were obtained using a questionnaire completed by an Ethiopian female assistant. These data included: clinic attended, ethnic group, religion, residence (urban/rural), age, age at first marriage, age at first coitus and relation to menarche, number of husbands/ sexual partners (sequential number of husbands; polyandry was not practised), last marital status/profession (single/married/ divorced $/$ widow $/$ housemaid $/$ talla seller [talla $=$ local beer]/prostitute/bargirl), number of years married, duration of sexual life, family monthly income, parity, total number of pregnancies, use of contraception (duration and type), past (self) history of STD and chief complaint. Clinical data were obtained from a full gynaecological examination by MED.

Blood was collected from all women by venepuncture; serum was separated and stored at $-20^{\circ} \mathrm{C}$. These sera were thawed for a minimum of five times for carrying out serological tests for other STDs: in Ethiopia for syphilis using VDRL and FTA, in Edinburgh for syphilis using TPHA ${ }^{18}$ and hepatitis B virus (HBV), ${ }^{19}$ in London for herpes simplex virus (HSV2) ${ }^{20}$ before they were tested for detection of chlamydial antibodies. The sera were subsequently tested in Copenhagen for Neisseria gonorrhoeae. ${ }^{21}$ The collection of data, cytology slides, and sera, and the VDRL test were done in 1975 and 1976, while ethnic, religious and other factors could still be assessed independently of population migration (as occurred during the Ethiopian revolution). It was not until 1977 and 1978 that specimens could be despatched from the country although full permission had been given by the Ethiopian Ministry of Health. Sera were stored at $-20^{\circ} \mathrm{C}$ until testing by micromethods became available. Sera were transported to the various laboratories on dry ice where they were stored at $-20^{\circ} \mathrm{C}$ until tested. These sera were tested in London during 1987 and 1988 by a modified micro-immunofluoresence (micro-IF) test $^{22}$ for the presence of type-specific anti-chlamydial antibodies. Antigens used were the following pools or representatives of purified chlamydial particles grown in fertile eggs: pool $1-C$. trachomatis A-C (CTA-C), pool 2-C. trachomatis D-K (CTD-K) pool 3-Lymphogranuloma venereum (LGV1-3) pool 4-C. pneumoniae (CPn), and pool 5-a negative control made of non-infected yolk sacs of fertile eggs. Sera were examined at a starting dilution of $1 / 16$ for anti- chlamydial IgG and 1/8 for anti-chlamydial IgM. The presence of specific IgG against one pool only, or at a higher level than the level of IgG against other pools, is considered specific IgG against a particular pool.

The results of micro-IF tests were interpreted as follows: (1) absence of antibodies is considered as having no exposure to chlamydial agents; (2) presence of antibodies to CTD-K and LGV1-3 is considered as having evidence of exposure to $C$. trachomatis genital infection; (3) presence of antibodies to CTA-C or $\mathrm{CPn}$ is considered as evidence of exposure to these mainly non-genital pathogens: (4) presence of IgM at a titre of $1 / 8$ or higher or IgG at a titre equal to or greater than $1 / 64$ to CTD-K or LGV1-3 was considered as being evidence of recent or present active genital chlamydial infection.

\section{Statistical methods}

Statistical analysis was made using first the Chi-square and then the Cochran-MantelHaenszel General Association Statistic ${ }^{23}$ to determine the significance level of any kind of association found between chlamydial seropositivity and other recorded data for the various groups of patients. The odds ratio (OR) and $95 \%$ confidence interval (CI) for association between genital chlamydial infection and other STD were computed using the latter statistic. Multivariate analysis of the most significant socioeconomic factors was made using stepwise logistic regression analysis; ${ }^{24}$ for this analysis patients with missing data for any one factor were omitted.

\section{Results}

Of 1846 women tested 1549 (84\%) were found to have IgG to chlamydia species, with titres $1 / 16$ to $1 / 8196$. Of these $1108(60 \%)$ had IgG to serovar CTD-K and LGV1-3, $138(8 \%)$ had IgG only to CTA-C and 303 (16\%) had IgG only to CPn. IgM was detected in 103 women (6\%) of whom 95 (5\%) had IgM to CTD-K or LGV1-3. The prevalence of IgG and/or IgM to genital chlamydial infection in patients attending GOPD, FPC, ANC and PNC was $63 \%$, $64 \%, 54 \%, 64 \%$ respectively, $62 \%$ overall. IgG at a titre of 1/64 or higher and/or IgM at a titre of $1 / 8$ or higher indicating recent or present active infection was detected in 767 (42\%) patients (table 1). The titres of genital chlamydial IgG are shown in table 2 . The geometric mean titre (GMT) of IgG to CTD-K and LGV1-3 was $1 / 83,1 / 96,1 / 64$ and $1 / 80$ for attenders at GOPD, FPC, ANC and PNC respectively.

The association of genital chlamydial infection with various epidemiological and socioeconomic factors is shown in table 3.

Using the Chi-square and Cochran-MantelHaenszel General Association Statistic we established a highly significant association between serological evidence for genital chlamydial infection and ethnic group, religion, age, age at first marriage, age at first coitus and its relation to menarche, number of husbands/ 
Table 1 Prevalence of antibodies to C. trachomatis serotypes $D-K$ and LGV1-3 in Addis Ababa, Ethiopia

\begin{tabular}{|c|c|c|c|c|c|}
\hline Patient group & No. tested & $\begin{array}{l}\text { No. (\%) with } \\
\text { IgG }\end{array}$ & $\begin{array}{l}\text { No. (\%) with } \\
\text { IgM }\end{array}$ & $\begin{array}{l}\text { No. (\%) with IgG } \\
\text { and/or IgM }\end{array}$ & $\begin{array}{l}\text { No. (\%) with } \\
\text { IgG/IgM suggesting } \\
\text { recent/present } \\
\text { infection * }\end{array}$ \\
\hline $\begin{array}{l}\text { GOPD } \\
\text { FPC } \\
\text { ANC } \\
\text { PNC } \\
\text { Total }\end{array}$ & $\begin{array}{r}960 \\
481 \\
306 \\
99 \\
1846\end{array}$ & $\begin{array}{r}585(61) \\
304(63) \\
160(52) \\
59(60) \\
1108(60)\end{array}$ & $\begin{array}{l}47(5) \\
21(4) \\
16(5) \\
11(11) \\
95(5)\end{array}$ & $\begin{array}{r}603(63) \\
307(64) \\
164(54) \\
63(64) \\
1137(62)\end{array}$ & $\begin{array}{r}407(42) \\
220(46) \\
96(31) \\
44(44) \\
767(42)\end{array}$ \\
\hline
\end{tabular}

$\star$ IgG $\geqslant 1 / 64$ and/or IgM $\geqslant 1 / 8$

Table 2 Distribution of IgM and titres of IgG for genital C. Trachomatis D-K and LGV

\begin{tabular}{|c|c|c|c|c|c|c|c|c|c|c|}
\hline \multirow{2}{*}{$\begin{array}{l}\text { Patient } \\
\text { group }\end{array}$} & \multirow{2}{*}{$\begin{array}{l}\text { No. } \\
\text { tested }\end{array}$} & \multirow{2}{*}{$\begin{array}{l}N o^{*} \\
\text { IgG/IgM }\end{array}$} & \multirow{2}{*}{$\begin{array}{l}\text { IgM† } \\
\text { only }\end{array}$} & \multicolumn{6}{|c|}{ IgG titre } & \multirow{2}{*}{$\begin{array}{l}\text { GMT } \\
\operatorname{IgG}\end{array}$} \\
\hline & & & & 16 & 32 & 64 & 128 & 256 & $512-8192$ & \\
\hline $\begin{array}{l}\text { GOPD } \\
\text { FPC } \\
\text { ANC } \\
\text { PNC } \\
\text { No } \\
\%\end{array}$ & $\begin{array}{r}960 \\
481 \\
306 \\
99 \\
1846 \\
(100)\end{array}$ & $\begin{array}{c}357 \\
174 \\
142 \\
36 \\
709 \\
(38)\end{array}$ & $\begin{array}{r}18 \\
3 \\
4 \\
4 \\
29 \\
(2)\end{array}$ & $\begin{array}{r}143 \\
65 \\
46 \\
18 \\
272 \\
(15)\end{array}$ & $\begin{array}{r}60 \\
24 \\
25 \\
4 \\
113 \\
(6)\end{array}$ & $\begin{array}{r}135 \\
77 \\
34 \\
14 \\
260 \\
(14)\end{array}$ & $\begin{array}{r}62 \\
46 \\
17 \\
5 \\
130 \\
(7)\end{array}$ & $\begin{array}{r}121 \\
50 \\
26 \\
10 \\
207 \\
(11)\end{array}$ & $\begin{array}{r}64 \\
42 \\
12 \\
8 \\
126 \\
(7)\end{array}$ & $\begin{array}{l}83 \\
96 \\
64 \\
80 \\
83\end{array}$ \\
\hline
\end{tabular}

* No genital CT antibodies detected in the tested sera

+ IgM only present without IgG
‡MT - Geometric mean of titre, calculated only for IgG.

Table 3 Evidence of exposure to genital $C$. trachomatis serotypes $D-K$ and LGV1-3 according to epidemiological and socioeconomic factors

\begin{tabular}{|c|c|c|c|}
\hline & No. tested & $\begin{array}{l}\text { CT positive } \\
\text { No. (\%) }\end{array}$ & $p$ value \\
\hline $\begin{array}{l}\text { Clinic attended } \\
\text { Gynaecological } \\
\text { Family planning } \\
\text { Antenatal } \\
\text { Postnatal } \\
\text { Total }\end{array}$ & $\begin{array}{r}960 \\
481 \\
306 \\
99 \\
1846\end{array}$ & $\begin{array}{r}603(63) \\
307(64) \\
164(54) \\
63(64) \\
1137(62)\end{array}$ & $<0.02$ \\
\hline $\begin{array}{l}\text { Age } \\
<20 \\
20-34 \\
35-49 \\
>50 \\
\text { Total } \\
\text { Ethnic Group }\end{array}$ & $\begin{array}{r}159 \\
1244 \\
384 \\
46 \\
1833\end{array}$ & $\begin{array}{r}82(52) \\
774(62) \\
251(65) \\
23(50) \\
1130(62)\end{array}$ & $<0.01$ \\
\hline $\begin{array}{l}\text { Amhara } \\
\text { Oromo } \\
\text { Tigre } \\
\text { Gurage } \\
\text { Others } \\
\text { Total } \\
\text { Religion }\end{array}$ & $\begin{array}{r}1077 \\
272 \\
148 \\
279 \\
65 \\
1841\end{array}$ & $\begin{array}{r}702(65) \\
176(65) \\
82(55) \\
141(51) \\
33(51) \\
1134(62)\end{array}$ & $<0.001$ \\
\hline $\begin{array}{l}\text { Ethiopian Orthodox } \\
\text { Moslem } \\
\text { Total } \\
\text { Origin of Residence }\end{array}$ & $\begin{array}{r}1623 \\
185 \\
1808\end{array}$ & $\begin{array}{r}1023(63) \\
93(50) \\
1116(62)\end{array}$ & 0.001 \\
\hline $\begin{array}{l}\text { Addis Ababa } \\
\text { Countryside } \\
\text { Total }\end{array}$ & $\begin{array}{r}1498 \\
314 \\
1812\end{array}$ & $\begin{array}{r}922(62) \\
197(63) \\
1119(62)\end{array}$ & NS \\
\hline $\begin{array}{l}\text { Age at first coitus } \\
<13 \\
13-15 \\
16-18 \\
>18 \\
\text { Total } \\
\text { Relation of first coitus to menarche }\end{array}$ & $\begin{array}{r}374 \\
771 \\
459 \\
170 \\
1774\end{array}$ & $\begin{array}{r}259(69) \\
499(65) \\
252(55) \\
78(46) \\
1088(61)\end{array}$ & $<0.001$ \\
\hline $\begin{array}{l}\text { Before menarche } \\
\text { After menarche } \\
\text { Total }\end{array}$ & $\begin{array}{r}777 \\
813 \\
1590\end{array}$ & $\begin{array}{l}525(68) \\
445(55) \\
970(61)\end{array}$ & $<0.001$ \\
\hline $\begin{array}{l}\text { Number of husbands/sexual partners } \\
1 \\
2-5 \\
>5 \\
\text { "Unknown" } \\
\text { Total } \\
\text { Last marital status/profession }\end{array}$ & $\begin{array}{r}798 \\
626 \\
264 \\
132 \\
1820\end{array}$ & $\begin{array}{r}435(55) \\
389(62) \\
206(78) \\
92(70) \\
1122(62)\end{array}$ & $<0.001$ \\
\hline $\begin{array}{l}\text { Last marital status/projession } \\
\text { Single } \\
\text { Married } \\
\text { Divorced } \\
\text { Widow } \\
\text { Housemaid } \\
\text { Talla seller } \\
\text { Prostitute } \\
\text { Bargirl } \\
\text { Total }\end{array}$ & $\begin{array}{r}17 \\
1076 \\
308 \\
43 \\
146 \\
119 \\
91 \\
32 \\
1832\end{array}$ & $\begin{array}{r}7(41) \\
609(57) \\
197(64) \\
28(65) \\
99(68) \\
87(73) \\
75(82) \\
27(84) \\
1129(62)\end{array}$ & $<0.001$ \\
\hline $\begin{array}{l}\text { Duration of sexual life (years) } \\
<10 \\
10-19 \\
>20 \\
\text { Total } \\
\text { Monthly Income (EB: } 2 E B=1 \text { SUS) }\end{array}$ & $\begin{array}{r}602 \\
742 \\
422 \\
1766\end{array}$ & $\begin{array}{r}339(56) \\
472(64) \\
274(65) \\
1085(61)\end{array}$ & 0.006 \\
\hline 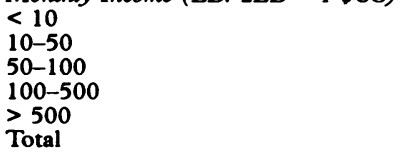 & $\begin{array}{r}330 \\
595 \\
152 \\
252 \\
64 \\
1393\end{array}$ & $\begin{array}{r}214(65) \\
387(65) \\
91(60) \\
135(54) \\
31(48) \\
858(62)\end{array}$ & 0.003 \\
\hline
\end{tabular}

NS = No significant statistical association sexual partners, last marital status/profession, duration of sexual life and income. There was a less strong but significant association between genital chlamydial infection and clinic attended, but no association between exposure to genital chlamydia pathogen and residence (rural or urban), obstetric history, parity or the total number of pregnancies, nor use and type of contraceptive. As the factors having significant association with genital chlamydial infection are not, of course, independent of each other, a multivariate analysis (MVA) was undertaken. For this analysis we used only socioeconomic factors, identified by the univariate analysis, as strongly associated with chlamydial infection (table 3 ). During the construction of the multivariate model, age at first marriage was found to be equivalent to age at first coitus; the sexual life duration factor had to be eliminated as it appeared to be just a linear combination of age at first coitus and present age of the patient. The stepwise method used selects the factors to be included in the model in order of likelihood.

The most significant factors in order of importance are age at first coitus (MVA $p$ value $<0.001$ ); religion (MVA $p$ value $<0.001$ ), prostitution (determined from last marital status/profession reduced to two groups: (i) prostitutes, bargirls, talla sellers and (ii) single. married, divorced, widowed, and housemaid) (MVA $p$ value $<0.001$ ); and present age of the woman (MVA $p$ value $<0.02$ ). When these factors are in the model the significance of other factors is marginal, which means they do not reach the significance level to be included in the model $(p>0 \cdot 1)$.

Seventeen women were single; data on age at first marriage were missing for $78 ; 99 \%$ of other women were married as virgins. Child marriage was frequently practised, sometimes the girl living with her mother-in-law until she was considered old enough for consummation of marriage. Five percent had first coitus older than first marriage; for the remaining women, age at first marriage and age at first coitus have the same value. It follows from this that these variables are equivalent for the statistical analysis and show the same association with other 


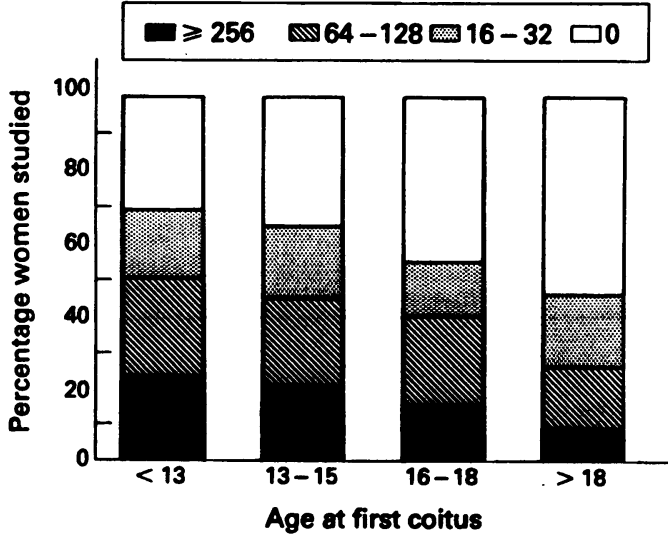

Figure 1 Prevalence and titre of genital chlamydia IgG according to age at first coitus. IgG titre $\geqslant 1 / 256=$ high level; titre 1/64-1/128 = intermediate level; titre $1 / 16-1 / 32=$ low level: $0=$ No IgG detected.

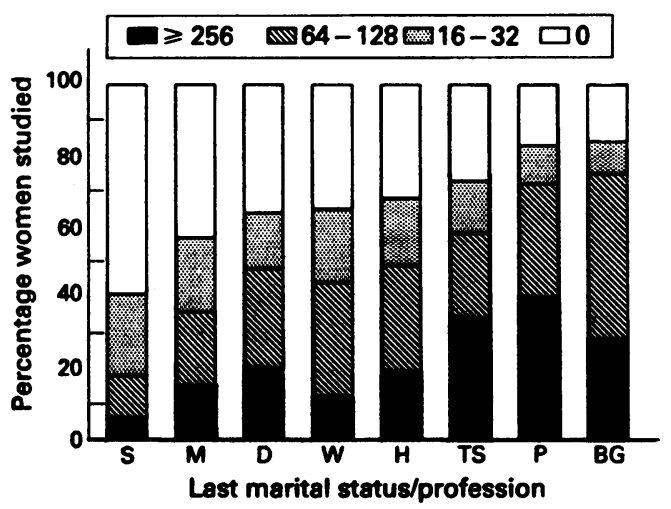

Figure 2 Prevalence and titre of genital chlamydia IgG chlamydial antibodies according to marital status/profession. IgG titre $\geqslant 1 / 256=$ high level: titre $1 / 64-1 / 128=$ intermediate level; titre $1 / 16-1 / 32=$ low level; $0=N o$ IgG detected. $S=$ single, $M=$ married, $D$ $=$ divorced, $W=$ widow, $H=$ housemaid, $T S=$ talla [local beer] seller, $P=$ prostitute, $B=$ bargirl.

factors. We report here the association with age at first coitus. The women married and sexually active at age under 13 years had significantly higher $(p<0.001)$ seropositivity $(69 \%)$ compared with those who were first sexually active aged over 18 years (46\%), largely due to increased prevalence of high titres (fig 1). Chlamydial infection was more frequent in those whose first coitus occurred before the age of the menarche which for most
Ethiopian girls occurred between the ages of 14 and 15 years.

There is a significant increase $(p<0.001)$ in genital chlamydial infection according to the marital status/profession (fig 2) from single (41\%) through married, divorced, widowed, prostitute, talla seller to bargirl $(84 \%)$ with the highest titres being found in prostitutes and talla sellers.

There was significant association between exposure to chlamydial genital species and seropositivity for syphilis (VDRL and TPHA), $N$. gonorrhoeae and HSV2 but no association between chlamydial seropositivity and that of Hepatitis B virus (HBV) as shown by SAg or $\mathrm{CAb}$. Table 4 shows the increased risk of exposure to genital chlamydial infection in those with other specified STD, compared with those without that condition (called odds ratio (OR)): this odds ratio is for those with syphilis $3 \cdot 1$, for those with gonorrhoea $2 \cdot 7$ and for those with HSV2 1.5. For HBV there is no significant increase.

\section{Discussion}

Most earlier seroepidemiological surveys of chlamydial genital infections in Africa have reported only on the prevalence rates according to age and sex of patient and clinic attended. A study reported earlier from Ethiopia showed that the prevalence of genital chlamydial IgG was $33 \%$ and $45 \%$, with IgM $18 \%$ and $26 \%$ respectively for men and women attending an STD clinic in Addis Ababa. ${ }^{6}$ In this study, in a different population, we report a higher prevalence $(60 \%)$ for genital chlamydial IgG and lower (5\%) prevalence for IgM. The sera used in this study had been thawed and re-frozen on several occasions. It is likely that much of the IgM originally present would have been destroyed, although the persistence of IgM in $5 \%$ of the sera may be indicative of a high level of infection initially. IgG is more stable. While we may have lost some IgG, the overall exposure to chlamydia pathogens is high $(84 \%)$, as is the prevalence of IgG to genital CT $(60 \%)$. It is unlikely that either prolonged storage or repeated thawing and freezing has greatly affected the prevalence or titres of genital chlamydial IgG although the GMT at the STD clinic $^{6}$ is higher, 1/193

Table 4 Seropositivity for genital chlamydia species $C$. trachomatis D-K and Lymphogranuloma venereum 1-3 according to seropositivity for other STD showing for each group the odds ratio (OR) and its $95 \%$ confidence interval (c.i.)

\begin{tabular}{|c|c|c|c|c|c|c|}
\hline$S T D$ & & $\begin{array}{l}\text { Tested } \\
\text { No. (\%) }\end{array}$ & $\begin{array}{l}\text { Positive } \\
\text { No. (\%) }\end{array}$ & $\begin{array}{l}\text { Negative } \\
\text { No. (\%) }\end{array}$ & $O R$ & $95 \%$ c.i. \\
\hline Syphilis (TPHA) & $\begin{array}{l}\text { Positive } \\
\text { Negative } \\
\text { Total }\end{array}$ & $\begin{array}{r}639(35) \\
1176(65) \\
1815\end{array}$ & $\begin{array}{r}497(78) \\
621(53) \\
1118(62)\end{array}$ & $\begin{array}{l}142(22) \\
555(47) \\
687(38)\end{array}$ & $3 \cdot 13$ & $2 \cdot 15-3 \cdot 89$ \\
\hline Gonorrhoea (GAT) & $\begin{array}{l}\text { Positive } \\
\text { Negative } \\
\text { Total }\end{array}$ & $\begin{array}{r}1071(59) \\
756(41) \\
1827\end{array}$ & $\begin{array}{r}764(71) \\
360(48) \\
1124(62)\end{array}$ & $\begin{array}{l}307(29) \\
396(52) \\
703(38)\end{array}$ & $2 \cdot 74$ & $2 \cdot 26-3 \cdot 32$ \\
\hline HSV2 & $\begin{array}{l}\text { Positive } \\
\text { Negative } \\
\text { Total }\end{array}$ & $\begin{array}{l}708(38) \\
1138(62) \\
1846\end{array}$ & $\begin{array}{r}480(68) \\
657(58) \\
1137(62)\end{array}$ & $\begin{array}{l}228(32) \\
481(42) \\
709(38)\end{array}$ & 1.54 & $1 \cdot 27-1 \cdot 88$ \\
\hline HBV & $\begin{array}{l}\text { Positive } \\
\text { Negative } \\
\text { Total }\end{array}$ & $\begin{array}{r}700(38) \\
1134(62) \\
1834\end{array}$ & $\begin{array}{r}439(63) \\
691(61) \\
1130(62)\end{array}$ & $\begin{array}{l}261(37) \\
443(39) \\
704(38)\end{array}$ & $1 \cdot 08$ & $0 \cdot 89-1 \cdot 31$ \\
\hline
\end{tabular}

TPHA = Treponema pallidum haemagglutination assay;

GAT = gonococcal antibody test;

HSV2 = Herpes simplex virus 2;

$\mathrm{HBV}=$ Hepatitis B virus. 
Table 5 Prevalence rates for genital C. trachomatis seropositivity in women

\begin{tabular}{|c|c|c|c|c|c|c|}
\hline Country & Author & Reference ${ }^{\star}$ & Clinic & Serovar & Post (\%) & GMT‡ \\
\hline Ethiopia & Forsey et al 1982 & 6 & $\begin{array}{l}\text { STD } \\
\text { Psych Hosp }\end{array}$ & CTD-K/LGV1-3 & $\begin{array}{l}45 \cdot 3 \\
11 \cdot 7\end{array}$ & $\begin{array}{l}1 / 193 \\
1 / 38\end{array}$ \\
\hline Nigeria & Darougar et al 1982 & 5 & $\begin{array}{l}\text { STD } \\
\text { FPC } \\
\text { ANC }\end{array}$ & $\begin{array}{l}\text { CTD-K/LGV1-3 } \\
\text { ", }\end{array}$ & $\begin{array}{l}26 \cdot 7 \\
35 \cdot 0 \\
10 \cdot 3\end{array}$ & $\begin{array}{l}1 / 71 \\
1 / 72 \\
1 / 29\end{array}$ \\
\hline $\begin{array}{l}\text { Gambia } \\
\text { Sudan } \\
\text { Algiers }\end{array}$ & $\begin{array}{l}\text { Mabey et al } 1984 \\
\text { Omer et al } 1985 \\
\text { Kadi et al } 1990\end{array}$ & $\begin{array}{r}8 \\
26 \\
9\end{array}$ & $\begin{array}{l}\text { ANC } \\
\text { STD } \\
\text { ANC } \\
\text { Prostitutes }\end{array}$ & $\begin{array}{l}\text { CTD-K } \\
\text { CTD-K } \\
\text { CTL2 }\end{array}$ & $\begin{array}{l}29 \cdot 4 \\
10 \cdot 4 \\
26 \cdot 6 \\
100\end{array}$ & $\begin{array}{l}\text { NAS } \\
1 / 26 \\
1 / 25 \\
1 / 371\end{array}$ \\
\hline UK & Forsey et al 1984 & 27 & $\begin{array}{l}\text { STD } \\
\text { GOPD }\end{array}$ & CTD-K & $\begin{array}{r}28 \cdot 7 \\
18 \cdot 8\end{array}$ & $\begin{array}{l}1 / 58 \\
1 / 33\end{array}$ \\
\hline UK & Darougar et al 1980 & 28 & $\begin{array}{l}\text { Blood } \\
\text { donors }\end{array}$ & CTD-K & 3.0 & NA \\
\hline Costa Rica & Vetter et al 1990 & 29 & $\begin{array}{l}\text { Population } \\
\text { Study }\end{array}$ & CTD-K & $56 \cdot 1$ & $\begin{array}{l}1 / 73- \\
1 / 102\end{array}$ \\
\hline Greenland & Mardh et al 1980 & 30 & $\begin{array}{l}\text { Population } \\
\text { Study }\end{array}$ & CTD-K & $51 \cdot 0$ & NA \\
\hline Iran & Darougar et al 1983 & 31 & $\begin{array}{l}\text { STD } \\
\text { prostitutes }\end{array}$ & CTD-K/LGV1-3 & $94 \cdot 2$ & NA \\
\hline
\end{tabular}

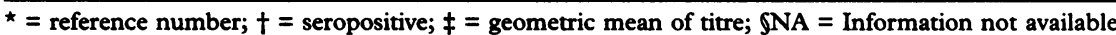

CTD-K = C. trachomatis D-K; LGV1-3 = Lymphogranuloma venereum 1-3; CTL2 = C. trachomatis L2.

compared with $1 / 83$ and $1 / 96$ for women attending GOPD and FPC respectively. The higher GMT in STD clinic patients may reflect more acute salpingitis ${ }^{25}$ and/or recurrent and upper genital tract infection.

The genital chlamydial infection prevalence rates and GMT for women in both studies from Ethiopia are higher than those from comparable clinics in Ibadan (Nigeria), the Gambia, Khartoum (Sudan), Algiers and London (UK) (table 5). The rates are comparable with those reported from population based studies in Costa Rica, and Greenland, which is said to have similar STD prevalence as in developing countries. ${ }^{30}$ Our results cannot be compared with reports of prevalence of chlamydial antigen in $19 \%$ ANC attenders in Somalia, ${ }^{10} 12 \%$ of IUCD acceptors in Kenya, ${ }^{32} 14 \%$ of gynaecological clinic attenders in the Gambia, ${ }^{33} 8 \%$ of women STD clinic attenders in Zimbabwe, ${ }^{11}$ or $10 \%$ of infertile women in Gabon ${ }^{12}$ as concurrent serological studies were not made. However, a small pilot study in Ethiopian infertile women showed that over $30 \%$ had chlamydia antigen in cervical secretions (M. Bekele personal communication) indicating that active chlamydial infection is as high if not higher in Ethiopia than elsewhere in Africa.

Possible reasons for the high prevalence of genital chlamydial infection in Ethiopian women are the asymptomatic nature of the infection, ${ }^{10}$ the assumption that PID is caused chiefly by $N$. gonorrhoeae which is highly prevalent, ${ }^{34}$ lack of diagnostic facilities, and inappropriate and inadequate treatment regimens especially for combined infections.

We could not compare our association of genital chlamydial infection with socioeconomic factors of other studies for lack of reference. The socioeconomic context of genital chlamydial infection in Ethiopia may be so specific that risk factors derived might not be valid if transferred into other cultural contexts. Undoubtedly there is cultural specificity not just between industrialised and developing countries but amongst different African countries. For this reason we preferred to show the association of genital chlamydial infection with each socioeconomic variable considered and their component cateories.

The multivariate analysis shows that prevalence of genital chlamydial infection and hence transmission of genital chlamydia pathogens is influenced particularly by age at first coitus, religion, prostitution, number of sexual partners and present age of the woman.

The significance of age at first coitus is of particular interest. Despite the fact that the overwhelming majority of women were first married as virgins, analysis of socioeconomic factors showed that the earlier the age at first marriage and hence first coitus, the shorter the duration of that first marriage, the greater the likelihood of divorce and remarriage or drift into prostitution. ${ }^{16}$

The effect of religion on the prevalence of chlamydial genital infection has been observed in Sudan where the prevalence of chlamydial genital infection, $10 \%$ of female patients at an STD clinic, ${ }^{26}$ is lower than that reported from elsewhere in Africa, although Somalia, a predominantly Moslem country, has a high prevalence of genital chlamydial antigen in the community: $18 \%$ of village women. ${ }^{10}$ Higher CTD-K antibody prevalence and C. trachoma$t$ is antigen has been reported from the Gambia for the Jola tribe, mostly Roman Catholic, compared with three other tribes, mainly Moslem. ${ }^{8}$ In Ethiopia, while child marriage was practiced by both Moslem and Ethiopian Orthodox women, very early age at first marriage was particularly a feature of the Amharas, the largest ethnic group in this study, 95\% of whom were Ethiopian Orthodox.

It was notable that those married and sexually active by the age of 13 years had one and a half times $(69 \%)$ the prevalence of genital chlamydial infection of those married over the age of $18(46 \%)$. The prevalence for high titres showed a 2.5 times increase, $22 \%$ compared with $8 \cdot 8 \%$. We have shown that coitus occurring before the menarche was a significant risk factor for STD because of anatomical, hormonal and immunological immaturity of the genital tract, as well as the presence of a male factor. ${ }^{16}$

As expected the increase in number of sexual partners is correlated with increased genital chlamydial infection confirming a similar trend 
reported from Costa Rica. ${ }^{29}$ The increased prevalence we report was due to high titre seropositivity, $12 \%, 19 \%$ and $35 \%$ for those with $1,2-5$ and $>5$ sexual partners respectively.

We have shown a clear association between genital chlamydial infection and last marital status/profession with prevalence of IgG increasing from $57 \%$ in married women to $73 \%$ in talla sellers and $82 \%$ in prostitutes, chiefly due to an increase in high titres (fig 2), and $84 \%$ in bargirls. We have shown a similar prevalence pattern with gonococcal antibody. ${ }^{35}$ High prevalence of genital chlamydial infection in prostitutes has been reported: $94 \%$ with IgG to CTD-K in Iran, ${ }^{31} 100 \%$ with IgG to CTL2 in Algiers, ${ }^{9}$ while chlamydia antigen was found in $39 \%$ and $65 \%$ of prostitutes in Cameroon and Côte d'Ivoire respectively. ${ }^{13}$ Prostitution is a factor for both acquisition and transmission of chlamydiae. ${ }^{516}$

We found genital CT IgG in $54 \%$ of routine asymptomatic ANC attenders and in $58 \%$ of women with no clinical evidence of pelvic infection (unpublished observations). These figures are midway in the scale of reported asymptomatic infection (23-79\%). ${ }^{5}{ }^{10}$ Untreated asymptomatic infection results in a reservoir of chlamydial pathogens in women. Willcox's classic observation could thus be amended to read "A promiscuous female pool (PFP) with many silent infections, infects a larger number of promiscuous males; these men feed back chlamydiae into the PFP and may also infect a non-promiscuous secondary contact, usually the wife" ${ }^{36}$ being as true of genital chlamydial infection as it was and is of gonorrhoea.

The increase in chlamydial seropositivity with age is mainly due to duration of sexual activity. We have shown an increase of seropositivity up to the age of 49 years with a drop thereafter confirming the report from Costa Rica $^{29}$ which is likely to reflect a diminution of sexual activity in post menopausal woman.

The high prevalence of chlamydial infection reported is for hospitals and clinics in the city of Addis Ababa. Increased urbanisation and the growing influence of western civilisation results in the break down of ethnic and cultural patterns of behaviour: ${ }^{38}$ women previously expected to retain their virginity until marriage may become sexually active prior to marriage. With increasing sexual licence, ${ }^{17}$ it is likely that prevalence of chlamydial genital infection will rise if the problem of chlamydial disease is not addressed urgently.

Further studies would be required in rural areas, where ethnic and cultural behavioural patterns are likely to be more stable, to show whether socioeconomic factors are of similar importance.

Few developing countries have diagnostic facilities for STD other than VDRL for syphilis; thus the prevalence of these infections is largely unknown. Use of micro-tests ${ }^{18-22}$ as seroepidemiological tools reveals the extent of the problem. We have shown a clear association between prevalence of chlamydia antibodies and seropositivity for syphilis, gonorrhoea and
HSV-2: those with these infections have an increased risk of genital chlamydial infection compared with those that do not. This suggests that there is some similarity in the risk factors for these STD. While it has been suggested that active chlamydia infection of the cervix per se may predispose to HIV acquisition, ${ }^{13}$ multiplicity of STD is a known risk factor for the transmission of HIV. ${ }^{39}$

The high prevalence of antibodies to genital chlamydia infection found in the study population must be taken as an index of the lack of understanding of chlamydiae as potential pathogens and hence inadequate treatment of symptomatic and asymptomatic women and men. Prevention of STD in general and chlamydial infection in particular requires education at all levels, training, information and counselling. This should be co-ordinated with various aspects of the campaign against AIDS. $^{40}$

We thank the staff and patients of St Pauls and the Black Lion Hospitals and Lidetta Clinic for their co-operation and $\mathrm{Dr}$ Philippa Wilson for her assistance in collecting data. We thank Drs $\mathrm{H}$ Young and J Peutherer and the Department of Medical Microbiology, University of Edinburgh for testing sera for evidence of syphilis and markers for hepatitis B, and Drs I Lind and $\mathrm{K}$ Reimann and the Neisseria Department of the Statens and Keruminstitut, Copenhagen for testing sera for antibodies to Neisseria gonorrhoeae. We acknowledge with thanks the financia assistance received from Allied Medical Group for the cost of the serological tests and and The Wellcome Trust for travel and secretarial expenses for MED. We thank Mrs M Pearce fo secretarial help.

1 Harnish JP, Berger RE, Alexander ER, Manda G, Holmes KK. Aetiology of acute epididymitis. Lancet 1977; 819-21.

2 Mardh P-A, Ripa KT, Svensson L, Westrom L. Chlamydia trachomatis infection in patients with acute salpingitis. $N$ Engl F Med 1977;296:1377-9.

3 Treharne JD, Ripa KT, Mardh P-A, Svensson L, Westrom L, Darougar S. Antibodies to Chlamydia trachomatis in acute salpingitis. Br $\mathcal{F}$ Venereal Dis 1979;55:26-29.

4 Hare MJ, Thin RN. Chlamydial infection of the lower genital tract of women. Br Med Bull 1983;39:138-44.

5 Darougar S, Forsey T, Osoba AO, Dines RJ, Adelusi B, Coker GO. Chlamydial genital infection in Ibadan, Nigeria. Br 7 Venereal Dis 1982;58:366-9.

6 Forsey T, Darougar S, Dines RJ, Wright DJM, Friedmann PS. Chlamydial genital infection in Addis Ababa, EthiopS. Chilamydial genital infection in Ad

7 Muir DG, Belsey MA. Pelvic inflammatory disease and its consequences in the developing world. $A m \mathcal{F}$ Obstet Gynecol 1980;138:913-28.

8 Mabey DCW, Lloyd-Evans NE, Conteh S, Forsey T. Sexually transmitted diseases among randomly selected attenders at an antenatal clinic in The Gambia. $\mathrm{Br} \mathcal{F}$ Venereal Dis 1984;60:331-6.

9 Kadi Z, Bouguermouh A, Djenoui T, Allouache A, Dali S Hadji N. Chlamydial genital infection in Algiers: a seroepidemiological survey. Trans $R$ Soc Trop Med Hyg 1990:
84:863-5.

10 Ismail SO, Ahmed HJA, Jama MA, et al. Syphilis, gonorrhoea and genital chlamydial infection in a Somali village. Genitourin Med 1990:66:70-5.

11 Masson PR, Gwanzura L, Latif AS, Marowa E. Genital infections in women attending a genito-urinary clinic in Harare, Zimbabwe. Genitourin Med 1990;66:178-81.

12 Leclerc A, Frost E, Collet M, Goeman J, Bedjabaga L. Urogenital Chlamydia trachomatis in Gabon: an unrecognised epidemic. Genitourin Med 1988;64:308-11.

13 Kaptue L, Zekeng L, Djoumessi S, Monny-Lobe M, Nichols D, Debuysscher R. HIV and chlamydia infections among prostitutes in Yaounde, Cameroon. Genitourin Med 1991;67:143-5.

14 Perine PL, Duncan ME, Krause DW, Awoke S, Zaidi AA Pelvic inflammatory disease and puerperal sepsis in Ethiopia. I. Etiology. Am $\mathcal{f}$ Obstet Gynecol 1980;138: 969-73.

15 Duncan ME, Perine PL, Krause DW, Awoke S, Zaidi AA Pelvic inflammatory disease and puerperal sepsis in Ethiopia II: treatment. Am $\mathcal{f}$ Obstet Gynecol 1980;138: 1059-63.

16 Duncan ME, Tibaux G, Pelzer A, et al. First coitus before menarche and risk of sexually transmitted disease. Lance 1990;335:338-40.

17 Plorde DS. Sexually transmitted diseases in Ethiopia. $\mathrm{Br} f$ Venereal Dis 1974;57:357-62. 
18 Young H, Henrichsen C, Robertson DHH. Treponema pallidum haemagglutination test as a screening procedure for the diagnosis of syphilis. Br 7 Venereal Dis $1974 ; 50$ : 341-6.

19 Peutherer JF, Mackay P, Ross R, Stahl S, Murray K. Use of hepatitis B antigen produced in Escherichia coli in an assay hepatitis B antigen produced in Escherichia
for anti-HBc. Med Lab Sci 1981;38:355-8.

20 Forsey T. Darougar S. Indirect micro-fluorescence test for detecting type-specific antibodies to herpes simplex virus.

21 Reimann K, Odum L, Larsen SO, Lind I. Indirect haemagglutination test using gonococcal pilus antigen: how useful to diagnose gonorrhoea? Genitourin Med 1987;63:250-55.

22 Treharne JD, Darougar S, Jones BR. Modification of the micro-immunofluorescence test to provide a routine sero diagnostic test for chlamydial infection. $f$ Clin Pathol 1977;30:510-7.

23 Mantel N. Chi-square tests with one degree of freedom: extensions of the Mantel Haenszel procedure. $9 \mathrm{Am}$ Stat extensions of the Mante
Assoc 1963;58:690-700.

24 Engelman L. Stepwise Logistical Regression. In: $B M D P$ Statistical Software Manual. Dixon WJ, Brown MB Statistical Software Manual. Dixon WJ, Brown MB,
Engelman L, Hill MA, Jennrich RI, Eds. University of California Press. Berkeley. Vol 2:1988:941-69.

25 Treharne JD, Ripa KT, Mardh PA, Svensson L, Westrom L, Darougar S. Antibodies to Chlamydia trachomatis in acute salpingitis. Br F Venereal Dis 1979;55:26-29.

26 Omer E-FE, Forsey T, Darougar S, Ali MH, El-Naeem HA Seroepidemiological survey of chlamydial genital infections in Khartoum, Sudan. Genitourin Med 1985;61: 261-3.

27 Forsey T, O'Connor BH, Azad A, West S, Darougar S, Adler W. Chlamydia trachomatis infection in women with acute pelvic inflammatory disease in London, England. Eur $f$ pelvic inflammatory
$S T D$
$1984 ; 1: 181-3$

28 Darougar S, Forsey T, Brewerton DA, Rogers KL. Prevalence of antichlamydial antibody in London blood donors. Br $\mathcal{F}$ Venereal Dis 1980;56:404-7.
29 Vetter KM, Barnes RC, Oberle MW, Rosero-Bixby L, Schachter J. Seroepidemiology of chlamydia in Costa Rica. Genitourin Med 1990;66:182-8.

30 Mardh P-A, Lind I, From E, Andersen A-L. Prevalence of Chlamydia trachomatis and Neisseria gonorrhoeae infections in Greenland. Br ₹ Venereal Dis 1980;56:327-31.

31 Darougar S, Aramesh B, Gibson JA, Treharne JD, Jones BR. Chlamydial genital infection in prostitutes in Iran. $\mathrm{Br} \mathcal{F}$ Venereal Dis 1983;59:53-5.

32 Sinei SKA, Schultz KF, Lamptey PR, et al. The prevalence of Neisseria gonorrhoea and Chlamydia trachomatis in intrauterine contraceptive acceptors in Kenya. $\mathcal{F}$ Obst Gyn East Cent Afr 1989;7:71-3.

33 Mabey DCW, Whittle HC. Genital and neonatal chlamydial infection in a trachoma endemic area. Lancet 1982;ii: 300-1.

34 Duncan ME, Reimann K, Tibaux G, Pelzer A, Mehari L, Lind I. Seroepidemiological study of gonorrhoea in Ethiopian women. 1. Prevalence and clinical significance. Genitourin Med 1991:67:485-92.

35 Duncan ME, Reimann K, Tibaux G, Pelzer A, Mehari L, Lind I. Seroepidemiological study of gonorrhoea in Ethiopian women. 2. Socioeconomic picture. Genitourin Ethiopian women. 2 .

36 Willcox RR. Importance of "feedback" in gonorrhoea control. Br f Venereal Dis 1965;41:87-91.

37 Verhagen AR, Gemert W. Social and epidemiological determinants of gonorrhoea in an East African country. Br ₹ Venereal Dis 1972:48:277-86.

38 Freedman RS. Aspects of Bantu domestic life in relation to some gynaeological conditions. S Afr Med f 1972;86: 1383-6.

39 Rowen D, Carne CA. Heterosexual transmission of human immunodeficiency virus. Int $\mathcal{f} S T D \mathcal{E}$ AIDS 1990;1: 239-44.

40 WHO collaborating centre for sexually transmitted diseases and their complications. Guidelines for the prevention of genital chlamydial infections. Geneva. World Health Organisation. 1990;24. 